\title{
伸線加工および変態時に導入された 転位への水素トラップと炭素偏析の競合現象
}

\author{
平上 大輔 ${ }^{1,5) *} \cdot$ 山﨑 真吾 ${ }^{2)} \cdot$ 樽井 敏三 $^{3)} \cdot$ 潮田 浩作 ${ }^{4,5)}$
}

Competitive Phenomenon of Hydrogen Trapping and Carbon Segregation in Dislocations Introduced by Drawing or Martensitic Transformation of 0.35 mass $\%$ and 0.8 mass\% C Steels

Daisuke HiraKami, Shingo Yamasaki, Toshimi Tarui and Kohsaku Ushioda

Synopsis : Hydrogen embrittlement has become a crucial issue with the promotion of high-strength steel. Many studies have been conducted on the mechanism of hydrogen embrittlement. Because the elucidation of the state of hydrogen is important to understand the mechanism, the states of hydrogen in the steels investigated were controlled. In the present study, 0.35 mass $\% \mathrm{C}$ and 0.8 mass $\% \mathrm{C}$ steels annealed in the hydrogen atmosphere followed by quenching from the austenite region together with drawn pearlitic steel of 0.8 mass $\% \mathrm{C}$ were used to analyze the state of the hydrogen contributing to the emission peak, in particular, at about $300{ }^{\circ} \mathrm{C}$ in the Thermal Desorption Analysis (TDA) curve. The peak at $300{ }^{\circ} \mathrm{C}$ was significant for quenched $0.8 \mathrm{mass} \% \mathrm{C}$ steel with low Ms temperature; however, the peak decreased with aging at room temperature. However, in 0.35 mass $\% \mathrm{C}$ steel with high Ms temperature, the peak at $300{ }^{\circ} \mathrm{C}$ was no longer observed. Moreover, in the hydrogen charged as drawn 0.8 mass $\%$ pearlitic steel, the peak at $300^{\circ} \mathrm{C}$ did not change with aging at room temperature because of no significant carbon in solid solution, while the peak at $100^{\circ} \mathrm{C}$ decreased with the increase in aging time. Taking into account the competitive phenomenon of hydrogen trapping at the dislocation core and $\mathrm{C}$ segregation to dislocations during room temperature aging or during quenching from Ms temperature, it was concluded that the hydrogen peak at about $300{ }^{\circ} \mathrm{C}$ is hydrogen trapped in the dislocation core, while the other hydrogen peak at $100^{\circ} \mathrm{C}$ is attributed to the hydrogen trapped by the stress field generated by dislocation.

Key words: hydrogen embrittlement; delayed fracture; hydrogen analysis; hydrogen trapping site; high strength steel.

\section{1. 緒言}

鋼材の更なる高強度化を推進する上で水素脆化はその阻 害因子となっており, 従来から水素脆化メカニズムに関す る多くの研究がなされている。一般的に, 環境から鋼材に 侵入した水素量が限界拡散性水素量を越えると水素脆化が 生じる ${ }^{1)}$ 。ここで, 限界拡散性水素量とは, 鋼材の強度レべ ルや応力状態で決定される水素量であり, これ以上の拡散 性水素が鋼材中に存在すると水素脆化が発生する。鋼材中 の水素の存在状態として格子間位置以外にも, 空孔, ボイ ド，転位や析出物界面などが知られている ${ }^{2-4)}$ 。格子間位置 に存在する水素は室温で容易に拡散する。例えば引張応力 下に揸炭素焼戻しマルテンサイト鋼の旧オーステナ イト粒界近傍に水素が拡散集積し, 粒界強度を低下させて 水素脆化を引き起こすことが知られている。微細析出物界 面の水素は界面の応力場にトラップされるため拡散が困難
となり，一般的に無害と考えられている。ボイドにトラッ プされる水素も同様である。一方, 水素は空孔や転位と相 互作用を持つ。すなわち, 水素は塑性変形で形成される空 孔との相互作用を通して空孔を安定化させると考えられ ている5)。また，水素は転位の応力場あるいは転位芯にト ラップされると考えられている ${ }^{5-7)}$ 。上記のように鋼材中 には様々なトラップサイトがあり, 水素脆化を議論するた めには鋼材中のどこに水素が存在しているのか, すなわち その存在状態を解明することが重要である。

水素の存在状態の解明には, マクロな実験手段として 昇温脱離分析 (TDA：Thermal Desorption Analysis) が良く 知られている ${ }^{8)}$ 。また最近では, 3DAP (Three Dimensional Atom Probe）を用いて微細Ti析出物近傍にトラップされた 水素の直接観察も報告されている ${ }^{9)}$ 。しかしながら, 格子 欠陷による水素トラップについては, 直接的な観察は一般 的に困難であり, 詳細な検討は行われておらず未だ明確に

平成26年6月3日受付 平成26年7月9日受理（Received on Jun. 3, $2014 ;$ Accepted on Jul. 9, 2014）

1）新日鐵住金 (株) 技術開発本部君津技術研究部 (Kimitsu R\&D Labs., Nippon Steel \& Sumitomo Metal Corporation, 1 Kimitsu Kimitsu City Chiba Prefecture 299-1141)

2）新日鐵住金 (株) 技術開発本部技術開発企画部（Technical Research \& Development Planning Div., Nippon Steel \& Sumitomo Metal Corporation)

3）日鉄住金テクノロジー（株）室蘭事業所（Muroran Div., Nippon Steel \& Sumikin Technology Corporation)

4）新日鐵住金 (株) 技術開発本部 (Technical Research \& Development Bureau, Nippon Steel \& Sumitomo Metal Corporation)

5）金沢大学大学院自然科学研究科 (Graduate School of Natural Science and Technology, Kanazawa University)

* Corresponding author : E-mail : hirakami.9fc.daisuke@jp.nssmc.com

DOI : http://dx.doi.org/10.2355/tetsutohagane.100.1322 
なっていないところも多い。

Takaiらは純鉄を用いて伸線加工を行い, 伸線加工ひず みの増加に伴って水素チャージ時にトラップされる水素 量が増加していることを示している ${ }^{10)}$ 。伸線加工ひずみの 増加に伴って転位, 原子空孔クラスターに起因した水素卜 ラップサイトが増加していると説明している。しかしなが ら, 転位による水素トラップ状態の詳細については明らか にしていない。

Matsui らは高純度鉄単結晶を用いて引張試験の途中で水 素チャージを行った。水素の存在によって高純度鋼では軟 化を示した ${ }^{11}$ 。矢の原因は，らせん転位の易動度が増加し たと推察されている。一方, 浅野らは高 $\mathrm{Cr}$ 鋼を用いて引張 試験の途中で水素チャージを行い, 水素の存在によって高 Cr 鋼では硬化を示した ${ }^{12)}$ 。その原因は水素による固溶強化 と推察されている。

Nagumoらは極低炭素鋼を用いて水素チャージ後の3点 曲げ試験を行って打り, 水素の存在によって延性き裂成長 抵抗が低下寸ることを示している ${ }^{13)}$ 。その原因として, 曲 げ試験時に転位間の相互作用により形成される空孔が水素 により安定化するため，延性き裂の伝播抵抗が低下すると 推察している。Enomotoらは，高強度マルテンサイト鋼の TDA曲線の予測を McNabb-Foster式 ${ }^{14)} に$ 転位へのC 偏析理

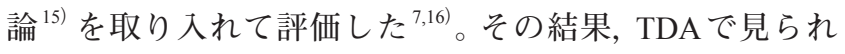
る二つのピークは, 転位の応力場にトラップされる約 100 ${ }^{\circ} \mathrm{C} に$ 現れる第一ピークと転位芯にトラップされる約 $300{ }^{\circ} \mathrm{C}$ に現れる第二ピークから成ることを実験と計算機シミュ レーションから明らかとした。しかし, 検討内容は計算機 シミュレーションが中心となって抲り, 実験的な検証には 未だ余地があるように思われる。

転位の力学挙動に及ぼす水素の影響として, 転位の易 動度が水素により助長されるHELP (Hydrogen Enhanced Localized Plasticity) 理論 ${ }^{17)}$ は良く知られている。その機構 として, 固溶水素が転位の回りに䨌囲気を作り応力場を緩 和させ，転位と障害物との相互作用を低下するモデルが 考えられている。一方, 武富らは第一原理計算を用いて, $\alpha$ 鉄中の刃状転位の運動に要するエネルギー障壁を NEB (Nudged Elastic Band) 法を用いて評価した ${ }^{18)}$ 。水素濃度が 低い場合には負荷応力に依存して転位の易動度の増加（軟 化）と減少（硬化）の双方が生じ, 水素濃度が高い場合には 硬化が生じることを示唆する結果を得た。

上記のように水素トラップサイトや水素と転位との相互 作用に関しては様々な議論があるが, 破壞の素過程の一つ
である塑性変形を支配する転位と水素との関係を理解する ことは重要である。

中炭素機械構造用鋼においては, 高強度鋼の代表組織で ある焼戻しマルテンサイト組織を利用するが, 焼入れ時の 変態の際に高密度の転位が導入される。また, 高炭素鋼線 では, 転位は線材の伸線加工を通して導入される。これら 熱処理時もしくは塑性加工時に導入される転位は, 応力負 荷時に水素と何らかの相互作用を起こすと推察される。一 方, 固溶炭素が存在すると, 転位への水素トラップと転位 への炭素の偏析は競合現象となることが予想される.羽木 らは極低炭素鋼を用いて塑性加工後の時効変化および水素 透過特性から水素と炭素が転位の応力場で偏析の競合が起 きていると推察している。しかしながら，時効特性は転位 の応力場だけではなく, 転位芯も影響を及ぼすことが考え られ，転位芯での競合現象についてはその関係はまだ明ら かにされていない。したがって, 水素脆化を理解するため には，さらに詳細に転位周りの水素の存在状態について理 解を深めることが重要である。

そこで, 本研究では, 転位と水素との相互作用を炭素の 転位への偏析を考慮して理解を深めることを目的に, 以下 の $2 つ の$ 検討を行った。一つ目は炭素量を変えた鋼を焼入 れる際に, マルテンサイト変態で導入される転位と水素と の相互作用をMs 点と冷却中の水素および炭素の転位への 拡散, および室温での時効現象の観点から調査することを 目的とした。二つ目は, 伸線加工によって導入される転位 と水素との相互作用について室温での時効時間を変化させ て調査することから, 水素の存在状態打よび水素や炭素と 転位との相互作用を明らかにすることを目的とした。常温 での時効に伴う硬度変化の起源を考慮して, 水素の転位に よるトラップメカニズムの妥当性を総合的に検証した。

\section{2. 実験}

\section{$2 \cdot 1$ 供試材}

供試材は高炭素鋼のSWRS82B（0.8 mass\% C 鋼）および SCM435（0.35 mass\% C 鋼）を用いた。SWRS82B は $122 \mathrm{~mm}$ $\times 122 \mathrm{~mm}$ 断面のビレットを $1100{ }^{\circ} \mathrm{C}$ に加熱後, $\phi 12 \mathrm{~mm}$ 打 よび $\phi 5.5 \mathrm{~mm}$ に熱間圧延した。圧延材の組織はパーライ 卜組織であった。また, SCM435は $85.0 \mathrm{~mm}$ の市販品を素 材とした。組織は球状化セメンタイトを第2相として含む フェライト組織であった。素材の化学成分を Table 1 に示 す。

Table 1. Chemical compositions of steels used (mass\%).

\begin{tabular}{c|c|c|c|c|c|c|c|c|c}
\hline & $\mathrm{C}$ & $\mathrm{Si}$ & $\mathrm{Mn}$ & $\mathrm{P}$ & $\mathrm{S}$ & $\mathrm{Cr}$ & Mo & $\mathrm{N}$ & $\mathrm{O}$ \\
\hline SWRS82B & 0.82 & 0.19 & 0.75 & 0.017 & 0.015 & - & - & 0.0035 & 0.0015 \\
\hline SCM435 & 0.35 & 0.21 & 0.73 & 0.016 & 0.012 & 1.01 & 0.19 & 0.0039 & 0.0012 \\
\hline
\end{tabular}




\section{$2 \cdot 2$ 伸線加工材の室温電解水素チャージ}

伸線パーライト鋼における水素の存在状態変化を調べる ため, $\phi 12 \mathrm{~mm}$ のSWRS82B を用いて $\phi 5.0 \mathrm{~mm}$ まで室温で 伸線を行い, 長さ $100 \mathrm{~mm}$ に切断し, その後陰極水素チャー ジを行った。陰極水素チャージ条件は，ガラス製の容器に 3 mass $\% \mathrm{NaCl}+3 \mathrm{~g} / 1 \mathrm{NH}_{4} \mathrm{SCN}$ 溶液 $500 \mathrm{~m} \ell$ を入れ, $\phi 0.5$ $\mathrm{mm}$ のPt線材を容器内側にらせん状に配したものの中心に サンプルを浸漬させた。この白金線に陽極，サンプルに陰 極を接続し, サンプルの表面積に対して $0.2 \mathrm{~mA} / \mathrm{cm}^{2}$ の電 流密度になるように電流を流し，室温にて水素チャージを 行った。水素チャージ時間は $18 \mathrm{hr}$ であり，水素チャージ終 了後, 超音波洗浄器にて2分間アセトン洗浄を行い, 乾燥 を行った。サンプルは，乾燥後直ちに液体窒素中に冷却し たものと, 大気中で 1 ヶ月間室温放置後に液体窒素中に冷 却したものを用意し，水素分析するまでの間，液体窒素中 に保管した。

\section{$2 \cdot 3$ 水素雰囲気加熱による水素チャージ}

高温で鋼材中に侵入させた水素の室温に打ける存在状 態の変化を調べることを目的に， $\phi 5.0 \mathrm{~mm} \times 100 \mathrm{mmL}$ の SCM435 および $\phi 5.5 \mathrm{~mm} \times 100 \mathrm{~mm}$ から $\phi 5.0$ まで研削を 行ったSWRS82B およびSCM435を用いて以下の熱処理を 行った。実験室に打いて $1 \mathrm{~atm}$ の水素雾囲気で $950{ }^{\circ} \mathrm{C} に 1$ 時 間加熱後, 油焼入れを行った。線径が $\phi 5.0 \mathrm{~mm}$ の場合, 950 ${ }^{\circ} \mathrm{C}$ で 1 時間加熱すると, 鋼材中の水素量は, 加熱䨌囲気の 水素分圧に平衡する水素量（約 3 mass ppm）で飽和してい ると考えられる。油焼入れ後，直ちにエメリ一紙にて表面 の付着物を除去するために金属光沢が出るまで研磨した。 SWRS82B は研磨直後打よび室温にて1 週間, 2 週間, 4 週 間，放置後に水素分析および硬さ測定を行った。SCM435 では, 研磨直後および室温にて1日，2日，4日，7日放置し， 1日，2日，4日，7日放置後の水素分析打よび，1日，2日， 4日，7日放置後の硬さを測定した。ビッカース硬度計を 用いて, $\mathrm{C}$ 断面の $90^{\circ}$ 毎に表層から中心までの距離の半分 の位置である $1 / 4 \mathrm{~d}$ 部の 4 箇所と中心の 1 箇所の硬さを測定 し，爷れらの平均硬さを代表的な硬度として用いた。

\section{$2 \cdot 4$ 鋼材中水素の分析方法}

水素分析は，ガスクロマトグラフィーを用いた昇温脱 離分析法にて行った。測定前にアセトンで $\phi 5 \mathrm{~mm} \times 100$ $\mathrm{mmL}$ の棒状試料を超音波洗浄し, 乾燥後に昇温用加熱炉の 中にある石英管中に挿入し，キャリアガスで置換が終了し た後に測定を開始した。アセトン洗浄から測定開始までの 間は, 約 12 分である。昇温速度は $100{ }^{\circ} \mathrm{C} / \mathrm{hr}$ であり，測定は $800{ }^{\circ} \mathrm{C}$ まで行った。また，高温側で発生するバックグラウ ンドを差し引くために, 測定終了後にサンプルを挿入した まま同条件で昇温分析した。測定值は, 各測定温度での初 回の分析結果から 2 回目の分析結果を差し引いたものを用 いた。

\section{3. 結果}

\section{$3 \cdot 1$ 伸線パーライト鋼の水素存在状態変化}

Fig.1 にSWRS82B (0.8 mass\% C 鋼) の伸線材を電解水素 チャージし, 室温にて放置した材料における水素の昇温離 脱曲線を示す。水素チャージ直後では, $100{ }^{\circ} \mathrm{C}$ 付近に第一 ピークの水素打よび $300{ }^{\circ} \mathrm{C}$ 付近に第二ピークの水素が見 られる。しかし，一ヶ月放置後には第一ピークの水素はほ ぼ消失するものの，第二ピークの水素は殆ど変化が見られ なかった。第一ピークの水素はEnomoto ら ${ }^{7}$ によると転位 の応力場にトラップされた水素でありトラップ力が弱い ため, 室温放置中に水素が拡散しサンプル表層から脱離し たためと考えられる。一方，高温側の第二ピークの水素は Enomoto $ら^{7)}$ によると転位芯にトラップされた水素と考え ら扎る。転位芯と水素との相互作用は強く, 室温では水素 が転位芯にトラップされたままの状態であり水素量に変化 がなかったものと推察した。

\section{$3 \cdot 20.8$ mass $\%$ C 鋼の水素雰囲気焼入れまま材の水素の 存在状態の変化}

Fig.2にSWRS82B ( 0.8 mass\% C 鋼) を 1atmの水素雾囲気 中で $950{ }^{\circ} \mathrm{C}$ に加熱し，油焼入れを行った試料を室温放置し た場合の水素の昇温離脱曲線を示す。 $0.8 \mathrm{mass} \% \mathrm{C}$ 鋼では, 焼入机直後では $100{ }^{\circ} \mathrm{C}$ 付近に第一ピークの水素打よび 300 ${ }^{\circ} \mathrm{C}$ 付近に第二ピークの水素が見られた。しかしながら, 室 温で 1 週間放置すると第一ピークの水素と共に第二ピーク の水素も著しく減少しており, Fig.1に示した 0.8 mass\% C 鋼の伸線パーライト鋼と大きく異なる挙動を示した。

Fig.3にSWRS82B (0.8 mass\% C 鋼) を $1 \mathrm{~atm} の$ 水素雾囲 気中で $950{ }^{\circ} \mathrm{C} に$ 加熱し, 油焼入れを行ったものの室温放置 に打ける硬さ変化を示す。室温に 1 週間放置すると硬さが 著しく増加しており，常温での時効により転位芯への炭 素の偏析が時間とともに進行し，2週間ほどで飽和状態に なっていることが示唆される。

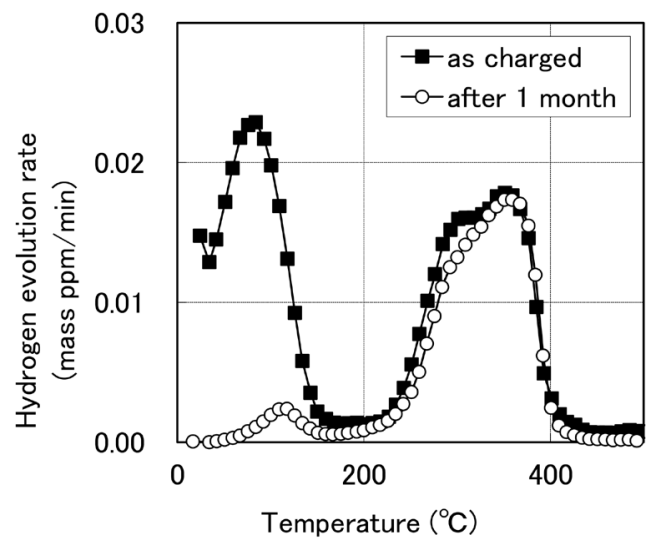

Fig. 1. Hydrogen thermal desorption analysis (TDA) curves for 0.8 mass $\% \mathrm{C}$ pearlitic steel drawn at $79.0 \%$ at room temperature together with that after aging at room temperature for 1 month. 


\subsection{35 mass\% C 鋼の水素雰囲気焼入れまま材の水素 存在状態変化}

Fig.4にSCM435（0.35 mass\% C 鋼）を用いて $1 \mathrm{~atm} の$ 水素 雲囲気中で $950{ }^{\circ} \mathrm{C}$ に加熱し, 油焼入れを行った場合の水素 昇温離脱曲線を示す。 0.8 mass $\% \mathrm{C}$ 鋼と異なり 0.35 mass $\% \mathrm{C}$ 鋼では, 焼入れ直後は $100{ }^{\circ} \mathrm{C}$ 付近の第一ピークの水素のみ 見られ, $300{ }^{\circ} \mathrm{C}$ 付近の第二ピークの水素は認められなかっ た。また，第一ピークの水素は放置時間が長くなると減少 する。第一ピークの水素は転位の応力場に弱くトラップさ れた水素と考えられるため, 室温で容易に拡散し表層から 離脱したためと考えられる。

Fig.5にSCM435 (0.35 mass\% C 鋼) を $1 \mathrm{~atm}$ の水素雰囲気 中で $950{ }^{\circ} \mathrm{C}$ 加熱し，油焼入れを行った試料の室温放置に おける硬さ変化を示す。この場合には室温放置しても硬さ の変化はない。これは, 室温放置による転位芯への炭素の 偏析に伴う時効硬化に時間依存性がないことから，油焼き 入れ中に炭素が転位に偏析したことを示唆している。上記 の推察は, Fig.4に示したように, 水素昇温脱離曲線に油焼 き入れままで $300{ }^{\circ} \mathrm{C}$ 付近の第二ピーク，すなわち転位芯に トラップされた水素のピークがないことに対応する。

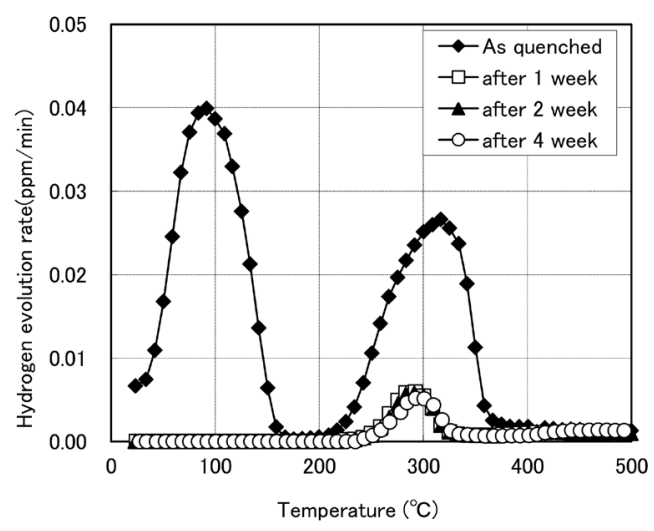

Fig. 2. Changes in TDA curves with aging at room temperature of 0.8 mass $\% \mathrm{C}$ steel annealed at $950{ }^{\circ} \mathrm{C}$ in hydrogen atmosphere followed by quenching.

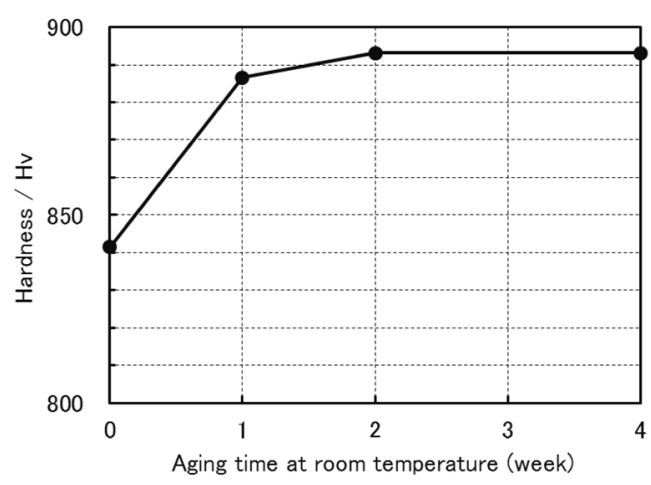

Fig. 3. Changes in Vickers hardness with aging at room temperature of 0.8 mass $\% \mathrm{C}$ steel annealed at $950{ }^{\circ} \mathrm{C}$ in hydrogen atmosphere followed by quenching.

\section{4. 考察}

$100{ }^{\circ} \mathrm{C}$ 付近の第一ピークの水素は, 0.35 mass\% $\mathrm{C}$ および 0.8 mass\% C 鋼の焼入れままおよび 0.8 mass \% C 鋼の伸線材 に認められ, Takai $~^{10)}$ が説明している, 原子空孔や転位の 応力場にトラップされた水素と推定される。一方, $300{ }^{\circ} \mathrm{C}$ 付近の第二ピークの水素は, 0.35 mass\% Cの焼き入れまま マルテンサイト鋼では見られず, $0.8 \mathrm{mass} \% \mathrm{C}$ のパーライ 卜鋼の伸線材および 0.8 mass \% C 鋼の焼入れまま材におい て見られた。また， 0.8 mass\% C 鋼の焼入れまま材を室温で 放置すると硬さが増加し, 一方では第二ピークの水素量が 減少した。したがって, 第二ピークの水素は, Enomoto ら ${ }^{7)}$ が指摘するように，転位芯へトラップされた水素と推察さ

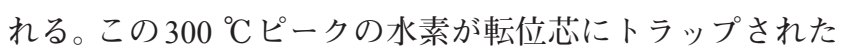
水素であることを, マルテンサイトの転位密度と水素およ び炭素の焼き入れ中の拡散から以下のように検証した。

Fig.6はマルテンサイト組織に打いて, 転位, および水 素, 炭素の位置関係を模式的に示す。ここで, 焼き入れま まマルテンサイトに打ける炭素量は今回実験に用いた 0.35 $\operatorname{mass} \%$ と $0.80 \mathrm{mass} \%$ に相当する量であり, 水素量は昇温脱

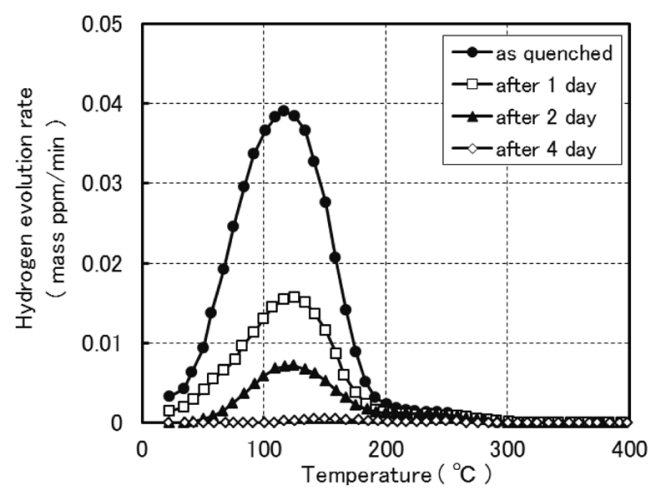

Fig. 4. Changes in TDA curves with aging at room temperature of 0.35 mass $\% \mathrm{C}$ steel annealed at $950{ }^{\circ} \mathrm{C}$ in hydrogen atmosphere followed by quenching.

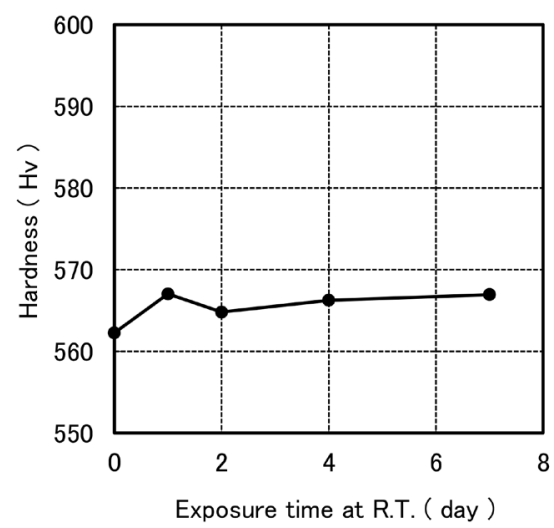

Fig. 5. Changes in Vickers hardness with aging at room temperature of 0.35 mass $\% \mathrm{C}$ steel annealed at $950{ }^{\circ} \mathrm{C}$ in hydrogen atmosphere followed by quenching. 
離法から得られた分析值の 3.0 mass ppmを用いた。転位密 度は一般的にマルテンサイト鋼で言われている $10^{16} / \mathrm{m}^{2}$ を 用いた。この転位密度の転位が均一に配置していると仮定 すると，平均的な転位間距離は $10 \mathrm{~nm}$ となる。また，水素の 平均原子間距離は4.06 nmであり，炭素の原子間距離は炭 素量が 0.80 mass\%のときには $0.680 \mathrm{~nm}, 0.35 \mathrm{mass} \%$ のとき には $0.897 \mathrm{~nm}$ である。したがって, 水素と転位との距離は $2.03 \mathrm{~nm}$, 炭素と転位との距離は炭素量が 0.80 mass $\%$ のと きには $0.340 \mathrm{~nm}$ ，炭素量が 0.35 mass\%のときには $0.449 \mathrm{~nm}$ である。

転位はマルテンサイト変態時に導入されるため, 転位芯 への侵入型固溶元素のトラップを検証するにはマルテンサ イト変態開始温度 $(\mathrm{Ms})$ 付近における水素や炭素の拡散係 数が重要となる。この際，転位を考慮した拡散を検討する 必要がある。すなわち，転位を利用せず体拡散する場合の 拡散係数 $\left(\mathrm{D}_{\mathrm{a}}\right)$ は，(1) 式のように表される。

$$
\mathrm{D}_{\mathrm{a}}=\mathrm{D}_{0} \exp (-\mathrm{Q} / \mathrm{RT})
$$

ここで, $\mathrm{D}_{0}=1.24 \times 10^{-5}\left(\mathrm{~m}^{2} / \mathrm{s}\right), \mathrm{Q}$ ：拡散の活性化エネ ルギーである。

一方，転位を利用した拡散係数 $\left(\mathrm{D}_{\mathrm{d}}\right)$ は，(2) 式のように 表される ${ }^{19)}$ 。

$$
\mathrm{D}_{\mathrm{d}}=\mathrm{D}_{0} \exp (-\mathrm{Q} / \mathrm{RT}) /\left\{1-\mathrm{K}_{\mathrm{d}}+\mathrm{K}_{\mathrm{d}} \exp \left(-\mathrm{E}_{\mathrm{d}} / \mathrm{RT}\right)\right\} \ldots \ldots \ldots
$$

ここで, $\mathrm{K}_{\mathrm{d}}$ : トラップサイト密度 $\left(=\pi \mathrm{r}^{2} \rho\right), \rho$ : 転位 密度 $\left(1 \times 10^{16} / \mathrm{m}^{2}\right), \mathrm{r}$ : 転位上の偏析半径 $\left(=1.0 \times 10^{-9} \mathrm{~m}\right)$, $\mathrm{E}_{\mathrm{d}}$ : 転位と侵入型固溶元素の相互作用エネルギー $\quad(=27$ $\mathrm{kJ} / \mathrm{mol}$ ) である ${ }^{19)}$ 。この Ed は転位の応力場におけるトラッ プエネルギーに相当する。

Fig.7 転位を考慮した拡散係数の温度依存性を示す。炭 素は各温度に打いて水素よりも拡散係数が小さく，特に $300{ }^{\circ} \mathrm{C}$ 以下の低温になるとその差が著しく大きくなる。

既に述べた転位と水素および炭素との距離を拡散する ための温度と時間の条件を Fig.8に示す。ここで，水素お よび炭素の拡散距離は上で求めた $\mathrm{D}_{\mathrm{d}}$ を利用して，(2D $\left.\mathrm{t}\right)^{1 / 2}$ を用いて求めた。Ms点を Andrews の式 ${ }^{20)}$ に基づき評価す

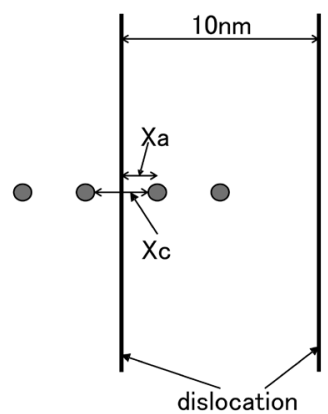

$$
\begin{aligned}
& \text { Dislocation density : } 10^{16} / \mathrm{m}^{2} \\
& \begin{array}{l}
\text { Mean inter-dislocation spacing : } \ell=\rho^{-1 / 2}=10 \mathrm{~nm} \\
\text { Inter-atomic distance }\left(\mathrm{Xc}_{\mathrm{c}}\right): \\
\mathrm{H} \quad: 4.06 \mathrm{~nm} \\
\mathrm{C}(0.35 \% \mathrm{C}) \quad: 0.897 \mathrm{~nm} \\
\mathrm{C}(0.80 \% \mathrm{C}) \quad: 0.680 \mathrm{~nm} \\
\text { Distance between } \mathrm{H}, \mathrm{C} \text { and dislocation }(\mathrm{Xa}): \\
\mathrm{H} \quad: 2.13 \mathrm{~nm} \\
\mathrm{C}(0.35 \% \mathrm{C}) \quad: 0.449 \mathrm{~nm} \\
\mathrm{C}(0.80 \% \mathrm{C}) \quad: 0.340 \mathrm{~nm}
\end{array}
\end{aligned}
$$

Fig. 6. Schematic illustration showing the arrangements of dislocations, and interstitial atoms such as hydrogen and carbon in martensite assuming their uniform distributions.
ると 0.35 mass\%鋼では約 $340{ }^{\circ} \mathrm{C}$ であるので，この場合には 転位への H と Cの到着時間がほぼ同じとなる。水素と炭素 の転位芯との結合 (トラップ) エネルギー ${ }^{16)}$ はそれぞれ 42 $\mathrm{kJ} / \mathrm{mol}^{21)}$ ，および $63.6 \mathrm{~kJ} / \mathrm{mol}^{22)}$ であり，0.35 mass\% C 鋼では 焼入れ時に既に転位芯にCがトラップされていると予想さ れる。

一方, $0.80 \mathrm{mass} \%$ 鋼では, Ms点が約 $220{ }^{\circ} \mathrm{C}$ と推定され 0.35 mass $\% \mathrm{C}$ 鋼より $120{ }^{\circ} \mathrm{C}$ 程度低温となる。したがって, Fig.8から明らかなように，この場合には焼入れ時に転位芯 に水素が先に到達していると推察される。しかしながら室 温で放置すると，転位周りに拡散してきた炭素は，水素と 比較して相互作用エネルギーが高いため，転位芯にトラッ プされている水素と置換すると考えられる。すなわち室温 での時効では, 転位芯トラップサイトにおいて水素から炭 素への置換が徐々に進行することで第二ピークの水素量は 低下し，一方では硬度が上昇すると考えられる。

以上の考察を模式的に示したものが Fig.9 およびFig.10 である。 $0.35 \mathrm{mass} \% \mathrm{C}$ 鋼と $0.80 \mathrm{mass} \%$ 鋼ではMs点が異な る。 Ms 点が高い 0.35 mass $\% \mathrm{C}$ 鋼では，転位周りに到着する 時間が水素と炭素でほぼ同じであるため, 焼入れままにお

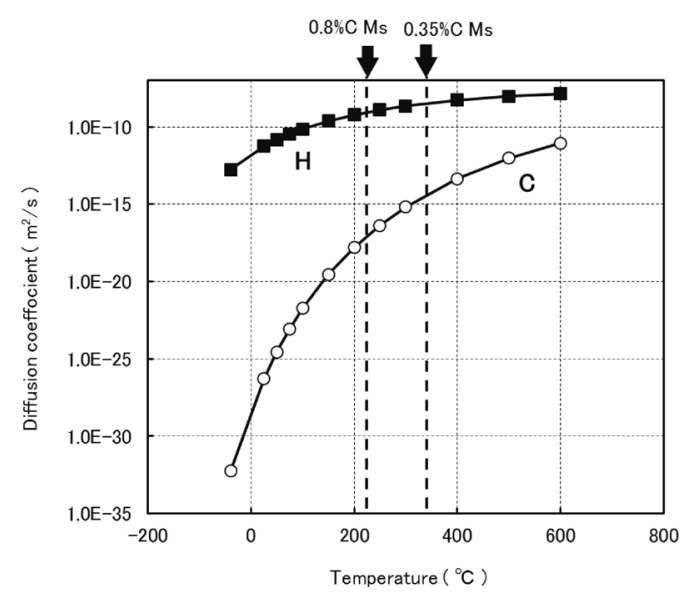

Fig. 7. Temperature dependence of diffusion coefficients of hydrogen and carbon taking into consideration the effect of dislocation.

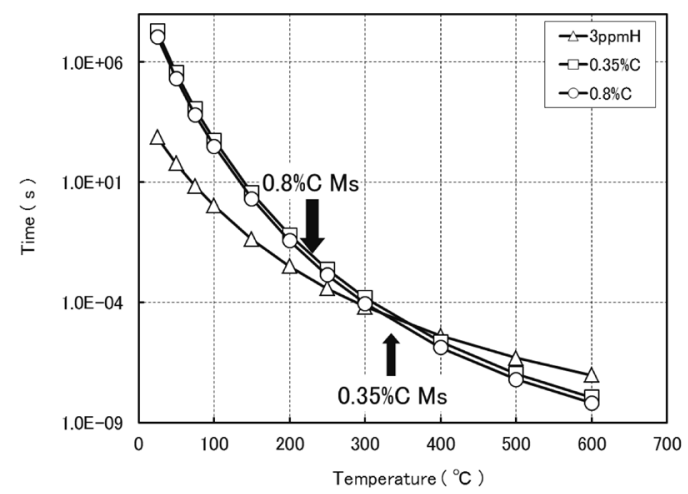

Fig. 8. Conditions for diffusion of hydrogen and carbon to reach dislocation in terms of temperature and time. 
いても転位芯はほぼ炭素で占有される。その結果, 焼入れ

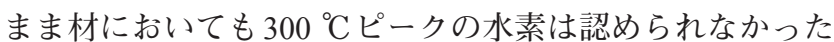
ものと考えられる（Fig.9a）。また，室温放置における硬さ の変化も現れなかったと推定される。

一方, $0.80 \mathrm{mass} \% \mathrm{C}$ 鋼においては Ms 点が低いため, 焼入 れ直後には転位芯に先に水素が到着・トラップされている ため, 水素昇温脱離曲線における $300{ }^{\circ} \mathrm{C}$ 付近の第二ピーク の水素として検出されたものと考えられる (Fig.9b)。しか しながら焼入れままマルテンサイトはマトリックス中に過 飽和に炭素が固溶しており，この固溶炭素は室温放置時に 転位に拡散し，Fig.10a）およびb）に示すように転位芯にト ラップされている水素と入れ替わることで $300{ }^{\circ} \mathrm{C}$ ピーク水 素量が減少し，一方では硬さが増加したと推察した。

0.80 mass\% C 鋼の伸線パーライト材は, 伸線加工により 導入された転位の応力場ならびに転位芯にトラップされた 水素がそれぞれ $100{ }^{\circ} \mathrm{C}$ 付近，および $300{ }^{\circ} \mathrm{C}$ 付近に観測され

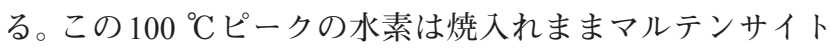
と同様に弱いトラップサイトであるため, 室温放置の際に 拡散し試料表面から放出されたため, 減少したと考えられ る。一方，転位芯にトラップされた水素は，焼入れままマ ルテンサイトと異なり, パーライト鋼では入れ換わる固溶
Cが殆ど無いために室温放置においても $300{ }^{\circ} \mathrm{C}$ 付近のピー クは減少しなかったと考えられる。この固溶 $\mathrm{C}$ 量の差が $0.80 \mathrm{mass} \% \mathrm{C}$ 鋼の伸線パーライトと焼入れままマルテンサ

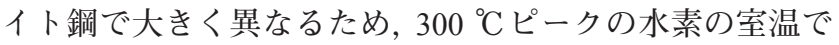
の時効に伴う挙動に著しい違いを生じさせたものと推定し た。

\section{5. 結言}

0.8 mass \% C 鋼の電解水素チャージした伸線パーライト 材および $950{ }^{\circ} \mathrm{C}$ 水素䨌囲気での加熱焼入れまま材，および $0.35 \mathrm{mass} \% \mathrm{C}$ 鋼の水素雲囲気での加熱焼入れまま材を用い て, 室温放置における鋼材中の水素の存在状態を昇温離脱 分析（TDA）および硬さ測定を行い調查し，以下の事を明 らかにした。

（1） $0.80 \mathrm{mass} \% \mathrm{C}$ 鋼の伸線パーライト材は，電解水素

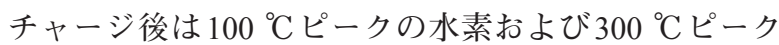

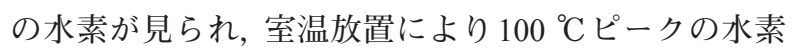
のみ減少した。

（2） 0.80 mass\% C鋼を水素䨌囲気で加熱後焼き入れた試 料は, 焼入れ直後は $100{ }^{\circ} \mathrm{C}$ ピークの水素打よび $300{ }^{\circ} \mathrm{C}$
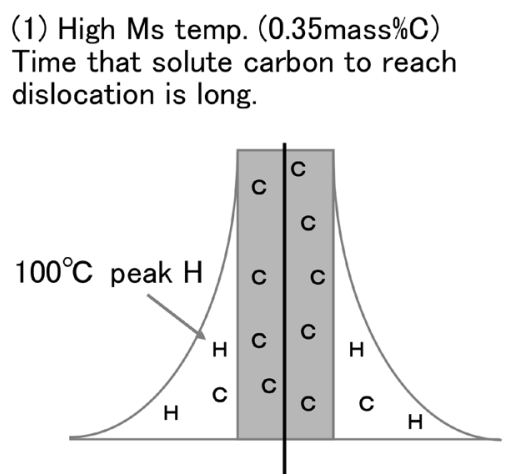

(2) Low Ms temp. (0.80mass\%C) Time that solute carbon to reach dislocation is short-

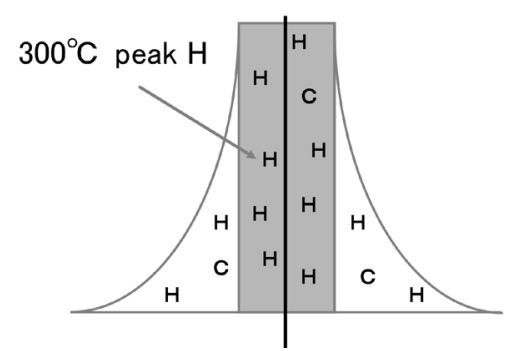

Fig. 9. Schematic illustration of hydrogen trapping and carbon segregation at dislocation core in steel with different Ms temperatures; a) 0.35 mass $\%$ C martensitic steel with high Ms temperature, and b) 0.8 mass $\%$ C martensitic steel with low Ms temperature.

(1) As Quenched Carbon is supersaturated in the matrix

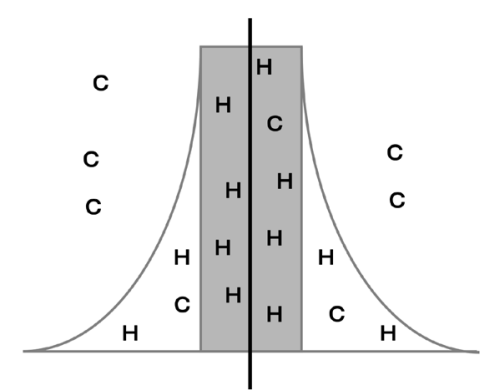

(2) Room temperature aging Carbon reached dislocation, and is replaced by hydrogen

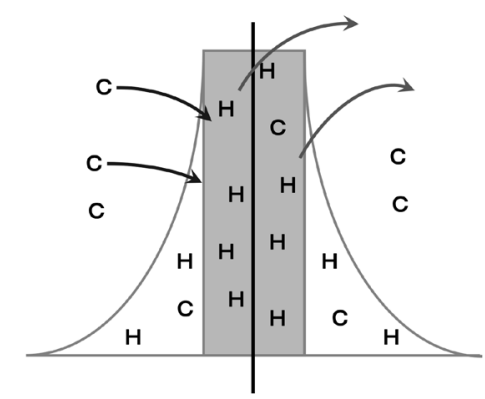

Fig. 10. Schematic illustration showing the change in segregated atoms in dislocations with aging at room temperature of 0.8 mass $\% \mathrm{C}$ martensitic steel; a) just after quenching, b) after aging at room temperature following quenching for a longer period. 
ピークの水素が見られたが，室温放置により $100{ }^{\circ} \mathrm{C}$

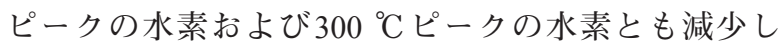
た。また室温放置により硬さが増加し，1週間で硬さの 増加がほほ飽和した。

（3）一方， 0.35 mass \% C 鋼を水素雰囲気で加熱後焼き入れ

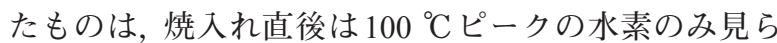

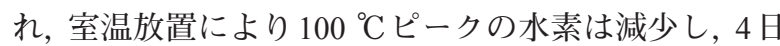
で消滅した。また，室温放置による硬さの増加は認め られなかった。

(4) 以上の実験結果より,

a) $100{ }^{\circ} \mathrm{C}$ 付近の第一ピークは転位の応力場, $300{ }^{\circ} \mathrm{C}$ 付 近の第二ピークは転位芯にトラップされた水素と 考えた。

b) 0.35 mass\% C マルテンサイト鋼は Ms 点が高いため, 焼き入れ中に転位芯に偏析していた水素が炭素の 偏析に置き換わるため，焼き入れままでも第二ピー クは存在せず，また室温時効による硬度変化もな かったと考えた。

c) 一方， 0.85 mass \% C ○テンサイト鋼の Ms 点は低 いため，焼き入れままでは炭素の転位への拡散は不 十分であり水素が転位芯に存在していたと考えた。 また，室温時効中に炭素は転位芯に拡散し，水素と 置き換わるため第二ピークは時効時間とともに低 下し，また時効硬化が認められた。

d）伸線パーライト鋼には固溶炭素はほとんど存在し ないと考えられ，したがって室温時効に伴い第二 ピークはほとんど変化しなかったものと推察した。

\section{文献}

1 ) 松山晋作 : 遅れ破壊, 日刊工業新聞社, 東京, (1989), 70 .

2 ) N.Abe, K.Suzuki, Y.Hagiwara and K.Takai: CAMP-ISIJ, 24(2011), 926, CD-ROM

3 ) H.G.Lee and J-Y.Lee: Acta Metall., 32(1984), 131

4 ) H.Yaguchi, T.Kochi, M.Nomura and T.Watanabe: J. Jpn. Inst. Met., 71(2007), 781

5 ) 南雲道彦 : 水素脆化の基礎, 内田老鶴圃, 東京, (2008), 299.

6 ) H.Hagi: Materia Jpn., 33(1994), 1407.

7 ) E.Enomoto, D.Hirakami and T.Tarui: Metall. Mater. Trans. A, 43A(2012), 572.

8 ) T.Tarui and S.Yamasaki: Tetsu-to-Hagané, 88(2002), 612.

9 ) J.Takahashi, K.Kawakami, Y.Kobayashi and T.Tarui: Scr. Mater., 63(2010), 261

10) T.Takai, G.Yamauchi, M.Nakamura and M.Nagumo: J. Jpn. Inst. Met., 62(1998), 267.

11) H.Matsui, A.Kimura and H.Kimura: Strength Metals Alloys, 2(1979), 977.

12) S.Asano, Y.Nishino and M.Otsuka: J. Jpn. Inst. Met., 43(1979), 241.

13) Y.Tokita, H.Katsumoto, H.Yoshida and M.Nagumo: CAMP-ISIJ, 12(1999), 546.

14) A.McNabb and P.K.Foster: Trans.TMS-AIME, 227(1963), 618

15) A.H.Cotrell and B.A.Bilby: Proc. Phys. Soc., A62(1949), 49

16) L.Cheng, M.Enomoto, D.Hirakami and T.Tarui: ISIJ Int., 53(2013), 131.

17) H.K.BirnBaum and P.Sofronis: Mater. Soc. Eng. A, 176(1994), 191.

18) 武富紳也, 松本龍介, 宮崎則幸 : 日本機械学会 M\&M材料力学 カンファレンス, (2010), 27.

19) H.Hagi and Y.Hayashi: J. Jpn. Inst. Met., 51(1987), 24.

20) K.W.Andrews: J. Iron Steel Inst., 203(1965), 721.

21) S.Taketomi, R.Matsumoto and N.Miyazaki: Acta Mater., 56(2008), 3761.

22) E.Clouet, S.Garruchet, H.Nguyen, M.Perez and C.S.Becqart: Acta Mater, 56(2008), 3450 